\title{
Factors Influencing the Use of Multimedia Technologies in Teaching English Language in Kuwait
}

\author{
https://doi.org/10.3991/ijet.v15i05.12277
}

\author{
Najla'a H. Al-Ajmi, Zainab M. Aljazzaf ${ }^{(凶)}$ \\ Kuwait University, Kuwait city, Kuwait \\ dr.zainab@ku.edu.kw
}

\begin{abstract}
The way of learning and teaching has been improved and the term of learning is developed. Generally, many researchers try to identify the important factors that affect the usage of multimedia in teaching and learning. However, there are few studies in this area specifically in Kuwait. Therefore, this study comes to fill this gab and identify the factors that influence the usage of multimedia technologies in teaching English language in Kuwait. Consequently, a research model is developed. To evaluate the proposed model, questionnaire is developed and the empirical data is collected and analyzed. The results reveal that there are seven factors that have an impact in using multimedia in teaching English subject, which are: facilitation, motivation, performance, behavioral, social, pedagogical, and effort factors. Moreover, the study proves that instructors have positive perceptions of multimedia technologies, but still need more supplements and supports.
\end{abstract}

Keywords - E-learning, Multimedia technologies, Education, Factors, Teaching English

\section{Introduction}

Mostly, people know the word "education" as lectures and classes taking place in educational institutions such as schools and universities. In addition, it includes a positive interaction between instructor and different levels of students. There are numbers of important concepts relate to terms of education, such as E-Learning, distance education, and adaptive learning. E-learning is meant to be the use of electronic media and information communication technology in teaching and education [1]. Elearning is the use of media components such as words and pictures to convey content and knowledge [2].

Multimedia technologies have emerged as a necessity to meet the challenges posed by the development of information technology in education. The utilization of multimedia technologies in teaching and learning is necessary and important nowadays due to its capability to deliver input learning easily [51][52][53]. Multimedia refers to channels, gadgets, and machines, which transmit information to learners [3]. It includes text, graphics, videos, audios and pictures. The multimedia learning theory 
principles state that students acquire language better from input enhanced by text and pictures than with text alone [4].

The utilization of information communication technologies in learning improves the learning skills and transforms the way of teaching as well as learning across the board. It develops principles and increases participation between students and their instructors. Moreover, it improves results in students' levels. Recently, applying technology in teaching is essential and becomes an important part of education [5].

However, the studies about multimedia in learning are very rare in Kuwait. For example [6] conducted a study about the impact of application of Information and Communication Technologies (ICT) in learning and teaching English language in girls' primary schools in Kuwait. Her study aimed to rise on teaching and learning English subject in primary schools. The result of the study proved that teaching with the help of ICT was very effective and beneficial for both teachers and students.

Moreover, another study in Kuwait [7] investigated students and instructors' perceptions toward the use of mobile devices in learning, and to understand the challenges that affect its implementation. The results revealed that students and instructors had positive perceptions of Mobile Learning (m-learning), and believed that $\mathrm{m}$-learning enhanced the teaching and the learning process. The study found some barriers to $\mathrm{m}$ learning implementation. The results revealed that students and instructors had positive perceptions of m-learning and believed that online social media applications could develop learning and enhance communications between students and instructors.

Since the study of the usage of multimedia technologies in teaching it is relatively new in Kuwait, this research comes to fill this gap. Specifically, this research mainly seeks to find out what factors influence the use of multimedia technologies in teaching English language in Kuwait. Specifically, it examines the following points:

- What are the effective factors influencing the use of multimedia technologies in teaching English language in Kuwait?

- Do multimedia technologies increase teachers' motivation?

- Do multimedia technologies facilitate the teachers' work?

- Does the social factor affect teachers' behavior to use multimedia technologies in teaching?

- Does multimedia increases the teachers' motivation?

The research methodology is as follows:

- Identify what are the factors that affect the use of multimedia technologies in teaching and learning English subject.

- Build a model and present the factors and hypotheses.

- Evaluate the model through questionnaire and data analysis.

The rest of the paper is organized as follows: Section 2 presents the literature review. Section 3 presents the related work. The research methodology is discussed in Section 4. Section 5 discusses the data analysis and findings. Discussion and conclusion are expressed in Section 6. 


\section{$2 \quad$ Literature Review}

All in all, the term "E-learning" is new way of education and many people still do not aware what exactly it means. Therefore, many research papers and many educational studies tried to explain and clarify the meaning of E-learning to get better understanding and provide general overview of this term. This section will go through the definitions of E-learning, advantages and disadvantages of multimedia technologies in learning, theories, and models.

\subsection{Definitions and terms of E-learning}

E- Learning means the systematic application of all bases of structured knowledge [8]. It is also clarified as the application a person can use in different ways to provide himself with information. Technology creates new way of learning and emerges with education. Mainly, it becomes an important aid in education courses. It supports the core of learning and facilitates the learning process. Moreover, traditional teaching transfers into online teaching, which leads to new figure of learning with networking technologies, so called electronic learning or E-learning.

Moreover, Rosenberg [9] defines E-learning as the process by which students obtain new skills or learn new information to improve their abilities and develop their skills. Also, the word learning defined as the process which people acquire new skills or knowledge for increasing and improving their ability in performance [9]. In addition, E-Learning is the use of media components such as words and pictures to convey content and knowledge [10]. It is also the use of technology tools and devices via computer and internet to improve learning skills and to clarify learning procedures [11]. E-learning is meant to be the use of electronic media and information communication technology in teaching and education [1].

\subsection{Multimedia}

Teaching now becomes easier and teachers could use printed pictures and audio sounds to make the students absorb knowledge in comfortable and easy way. Additionally, all the thanks go to the progression of technology and computer system. Since technology invaded the world, the method of learning has been changed and the reliance on written and spoken words as the major aspects of teaching is no longer existed. Multimedia enables instructors to benefit from different types of Medias to make teaching smooth and obvious for both teachers and students [1].

Multimedia is defined as a combination of computer networks and video technology; it is a mixture between hardware and software as well as media components [12]. Moreover, multimedia also refers to the development and the utilization of different types of media and communication technologies to improve content visualization and use collaboration [13]. Multimedia has different components that facilitate learning process and teaching system. The multimedia components include pictures, videos, 
audios, information communication technology and everything relates to computer networks [1].

\subsection{Advantages and disadvantages of multimedia}

The following sections will explain the advantages and the disadvantages of multimedia technologies.

Advantages of multimedia: Through multimedia technology, student can discuss, do assignments, study, and attend online classes [14]. Multimedia expands the experiences and the skills of learners through the use of the internet and the availability to gain plenty of information. It gives the students the ability to share their ideas and discuss it with the instructors as well as their colleagues through participation groups. It also engages students to improve communications and reduce shyness between them. Moreover, it encourages students for cooperation and interaction. Through interaction, student can have the opportunity to exchange information and bring new ideas [15].

The disadvantages of multimedia: Multimedia has many limitations and disadvantages that may face learners while attending online classes. One of the major weaknesses of E-learning and multimedia technologies is the isolation. Students work online from home or any place they feel comfortable to study in alone with their machines and that leads to the absence of social interactions between learners and their teachers. Also, the lack of computer skills and the poor experience of using multimedia aids will effect on students' attention and will waste teachers' time [16].

Moreover, using technology in learning will have negative influence in communication skills. In addition, multimedia technologies is a strategy of learning that uses open internet which indicates to the difficulties in controlling cheating in exams and doing class assignments [17].

\subsection{Theories}

Through many years, number of researchers have adopted, modified, and validated many theoretical models in order to explain, understand, and predict technology. This section presents different models that are related to multimedia technologies applications. Figure 1 shows the most important components in multimedia technologies. The figure contains six essential characteristics, which are image, charts, video, text, animation, and audio. 


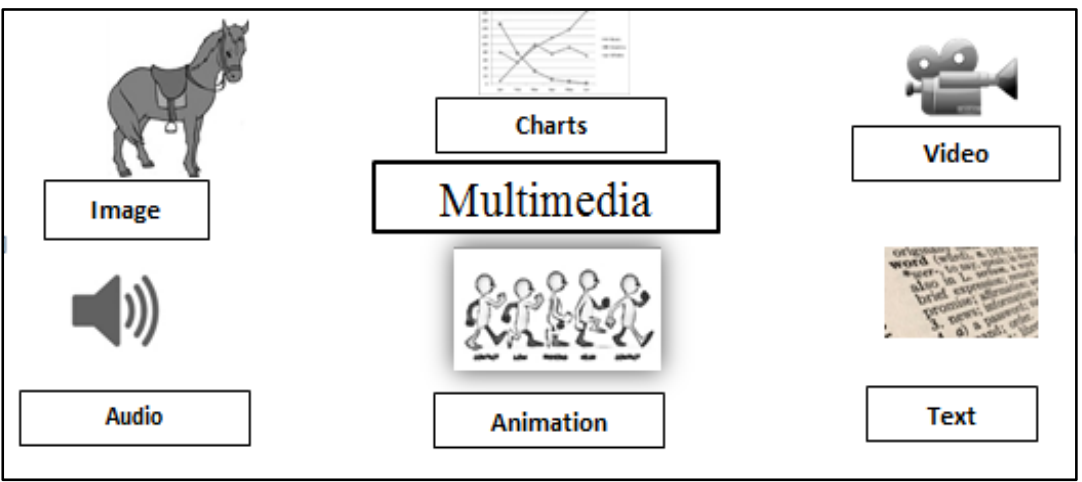

Fig. 1. The Most Common Components in Multimedia Technologies.

Moreover, the most common theory in multimedia is Cognitive Theory Multimedia Learning (CTML), which is built up by Mayes and Freitas [18]. This theory supports the arguments that the brain learns more deeply from words and pictures. Using multimedia means to use more than one media to deliver the information. Mayer [19] suggests that multimedia learning happens when we shape mental representations from words and pictures. The words can be spoken or written, and the pictures can be any form of graphical images containing photos, animation, illustrations, or video.

Figure 2 shows the Cognitive Theory Multimedia Teaching. There are three types of memory: sensory memory, working memory, and long term memory [19]. At the beginning, both pictures and words come from outside world as a multimedia presentation into the sensory memory through human senses (eyes and ears). Then, the sensory memory stores the printed words and pictures as visual image for limited time in sensory memory box. After that, words and pictures transform inside the working memory to form ideas and create mental and coherent information. Working memory is the main work of multimedia learning processes, which deals with active consciousness. For example, if we look at huge picture, our mind concentrate only on specific parts in the image; or if we read some sentences our mind will focus on exact words of statements at one time. This type of process involves conscious awareness, which takes place in the working memory.

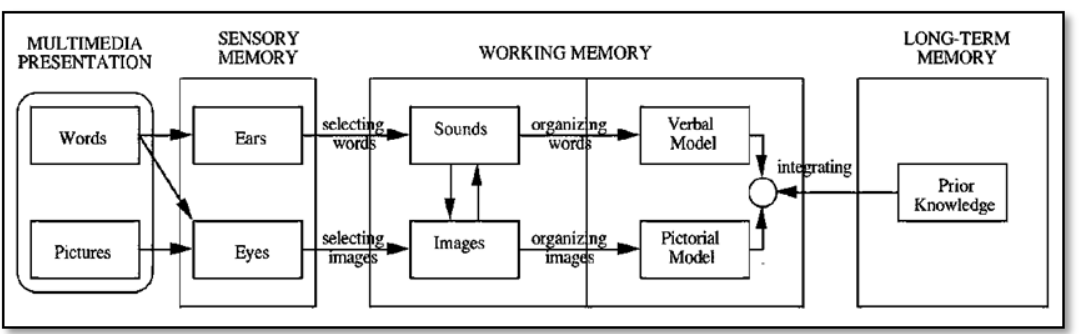

Fig. 2. Cognitive Theory Multimedia Teaching [19]. 


\section{Related Work}

There are different researches that define multimedia technologies and describe the importance of multimedia in teaching English language. However, it is important to clarify that there are few studies about multimedia technologies in education in $\mathrm{Ku}$ wait. Hence, discussion on the same might not be rich enough. Therefore, providing a highlight on multimedia technologies in teaching in the state of Kuwait will be quite challenging.

\subsection{Studies show the importance of using multimedia in teaching English language:}

Ramírez [20] clarified the reasons behind the uses of multimedia visual aids in English language classrooms at Margarita Salas high school. The study proved that multimedia technologies in teaching English language make a dynamics change in English classrooms. It showed that the use of multimedia helped to attract students' attention, enhanced and facilitated comprehension of the second language as well as helped students to memorize vocabulary and structure and to increase their motivation.

Moreover, Yunus et al. [21] conducted a study in Malaysia about using visual aids in teaching English language. The results of this study showed positive attitude of teachers towards using visual aids in teaching English literature. Using visual aids in teaching English literature was useful for English teachers and other educational institutions. It also made an effective teaching and learning process.

Fatehi [4] explained the effectiveness of using videos in teaching grammar. The aim of the study is to explore the role of enhanced video subtitles in teaching grammar classes. The author used experimental method and questionnaire to measure the students' perceptions towards using videos in teaching grammar. The study emphasized the importance of using videos and multimedia technologies in enhancing learners' results and developing their achievements in grammar classrooms. The use of the subtitled video facilitated the recognition of the grammatical structure in context.

Al-Mutairi [6] conducted a study about the impact of application of ICT in learning and teaching English language in girls' primary schools in Kuwait. The study aimed to develop a deeper understanding of teaching and learning of English as a second language by Kuwaiti females in primary schools. The result of the study proved that teaching with the help of ICT was very effective and beneficial for both teachers and students. In addition, it made learning easy and fun. Moreover, the research would help to support the previous studies in adopting multimedia in teaching English language in Kuwait public schools. 


\subsection{Studies that considered the factors that affect the use of multimedia in teaching}

Inan and Lowther [23] investigated factors affecting technology integration in K12 classrooms. The study built a model and included many factors, which are: demographic factors, which included: age, years of teaching, and computer proficiency. Also, computer availability, teachers' beliefs, teachers' readiness, overall support, technical support, and technology integration The results proved that the model was partially supported by the findings and provided significant evidence that the developed model is useful in explaining factors affecting technology integration.

Moreover, Saadé and Galloway [24] measured the acceptance of students towards using MultiMedia Learning System program (MMLS) in learning. The purpose of the MMLS was to provide students with a multimedia environment to learn the concepts of entity relationship diagrams. The study was based on the Technology Acceptance Model (TAM). The study was built by four main factors: perceived usefulness, perceived ease of use, attitude, and intention to use. The study aimed to show the importance of using online applications in learning as well as to improve online learning via multimedia tools. The results of the study showed that the use of MMLS application was very useful and students had a good attitude toward using it.

A study conducted by Tarhini et al. [25] aims to test the factors that effect on student's acceptance and usage of web-based Learning systems in Lebanon. They built their study following the TAM method. The factors are perceived usefulness, perceived ease of use, social norms, quality of work life, and behavioral intention. The results of the study revealed that E-learning was well accepted in Lebanon.

Another study conducted by Abdulkafi [26]. The researcher followed a descriptive study. The results concluded that teachers had positive attitudes toward ICT in education. Teachers' attitudes were predicted by computer attributes, cultural perceptions, and computer competence. The outcomes pointed to the importance of using ICT in teaching and learning.

Gilakjani and Ahmadi [27] focused on learners' individuals and learning styles. The researchers classified the students as visual, auditory, and kinesthetic. According to this classification the researchers built their study based on Multiple Intelligences Theory (MIT), which was important to cognitive science. They focused on multimedia technologies. The results showed that the prevalent learning style among English Foreign Language (EFL) students in Islamic Azad University of Lahijan in Iran were visual learners. The purpose of this study was to increase faculty awareness and understanding of the impact of multimedia tools on the teaching process.

A study conducted by Al-Doub [28] aims to presents an overview of students' attitudes towards E-learning in Kuwait. The researcher built his study based on many factors, which are: demography, facilitation, satisfaction, utilization, and attitude of students. The researcher followed the quantitative methodology to make his study. The study showed significant differences between private sector and governor sector also between male and female students. These differences should be taken into account when implementing E-learning program. 
Aloraini [29] conducted a study to find out the influence of using multimedia in teaching computer and its uses in teaching. The researcher used the experimental method to evaluate the groups. The results of the study showed significant differences between the experimental group and the control group in a favor of experimental group. This study confirmed the importance of multimedia technologies in enhancing learners' results and developing their achievements.

\subsection{Studies that focused on multimedia challenges}

Moreover, Gokah et al. [30] highlighted the challenges and the opportunities that face E-learning in higher education in Dubai. The findings of this study showed significant differences in satisfaction and dissatisfaction about using E-learning in higher education. Some of these issues were related to technical problems in some universities in Dubai. Other challenges were associated with weak internet connection and lack of improved computer skills. These issues gave more opportunities to bring new strategies in applying E-learning in Arabian Gulf.

Another study in Kuwait by Al-Hunaiyyan et al. [7], aimed to investigate students' and instructors perceptions toward the use of mobile devices in learning, and to understand the challenges that affect its implementation. The researchers laid on many factors, which are: demography, technical challenges, social challenges, mobile challenges, design challenges, management challenges, pedagogy challenges, and evaluation challenges. The results revealed that students and instructors had positive perceptions of m-learning and believed that online social media applications could develop learning and enhance communications between students and instructors.

Another study conducted by M. Alkharang and Ghinea [31] aimed to investigate the experiences and the challenges included with the basic barriers of adopting Elearning in higher institutions in Kuwait. The researchers built their study by seven important factors, which are: management awareness, language barriers, performance expectancy, effort expectancy, social influences, facilitating conditions, and behavioral intention. They also used many methods, such as TAM and UTAUT. The results of the study showed that the main barriers in Kuwait were lack of management awareness and support, technological barriers, and language barriers.

Each study in the previous work concentrated on one side only in multimedia technologies or focused on limited issues. Moreover, some of these studies concentrated on barriers and tried to find solutions. Others focused on students' perceptions only. Furthermore, certain studies concerted on both students and teachers perceptions. In addition, there are research papers that examined E-learning in general with both barriers and benefits. Others did not specify the levels and the stages of students. This research paper concentrated on teachers' perceptions towards the effective factors in using multimedia technologies in teaching English language in the state of Kuwait. 


\section{$4 \quad$ The Research Methodology}

This section presents the data methodology, and this includes the research model and questionnaire.

\subsection{The research model}

This section presents the research proposed model, as shown in Figure 3. The figure displays the factors and relationship among them that represent the hypotheses. The proposed model is built based on TAM model and places other constructs that are extracted from the literature. This model comes to focus on the factors that influence the usage of multimedia technologies in teaching English language in Kuwait. It focuses on twelve factors and they are demographic, facilitation, motivation, knowledge, performance, technical, social, time, financial, effort, pedagogical, and behavioral intention. The following presents the discussion of the factors in the research proposed model and the hypotheses.

Facilitation factor: Facilitating conditions are defined as the degree which users believe that an organizational and technical infrastructure exist to support the use of a certain technology [32]. Alkharang [33] uses facilitation factor to measure the perception of teachers about accessing online classes. In this context, facilitation refers to teachers' perceptions of the availability of resources and support to use multimediaenhanced content in teaching English subject. Therefore, the hypothesis is derived as follows:

H1: Facilitation factor has an effective impact on multimedia technologies in teaching English language.

Social influence factor: Social influence is the degree to which users perceive that important others (e.g., family and friends) believe they should use a particular technology [34]. In the context of this study, it represents the degree to which teachers perceive that others believe they should use multimedia technologies in their classes. According to social influence theory, users tend to comply with other important referees' opinions. Therefore, it is important to contain social influence as a factor in the research model and this leads to the following hypothesis:

H2: Social factor has an effective impact on using multimedia technologies in teaching English language. 


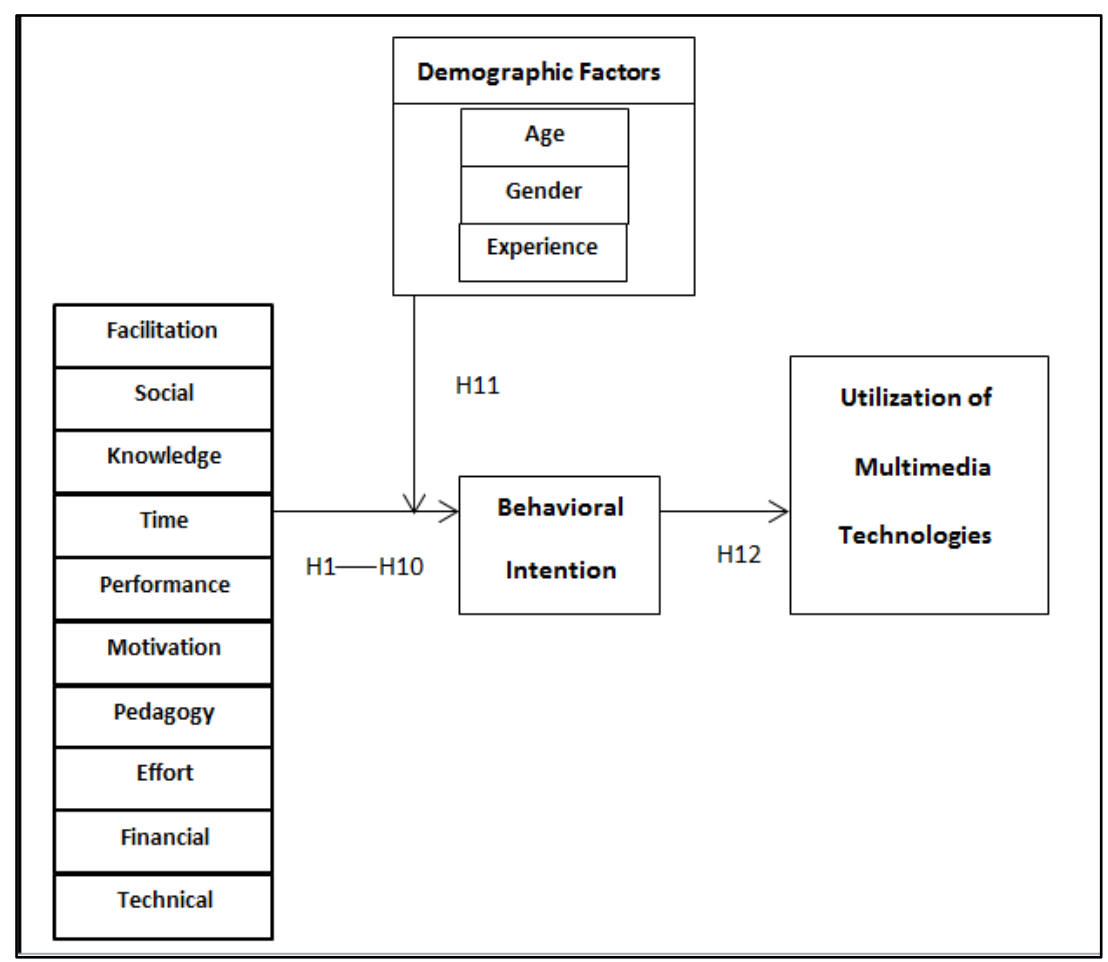

Fig. 3. The research model

Knowledge factor: This factor represents the background of teachers' familiarity in using multimedia technologies, such as computer. It is important for all teachers and decision-makers in educational institutions to know the benefits, facilities, and services of multimedia technologies and their importance in relation to their specific tasks [35]. The motivation for the researcher in this study is to measure the effectiveness of technology on teachers' performance and to investigate the fact that the performance expectancy is a strong predictor of behavioral intention toward technologies. This leads to the following hypothesis:

H3: Knowledge has an effective impact in using multimedia technologies in teaching English language.

Time factor: Teachers' career involves with limited time in preparing and explaining their lessons. For this reason, time forms an important factor in using multimedia technologies in teaching English subject. This research uses time as a factor to measure the effectiveness of time in using multimedia technology in teaching English subject. Thus, this leads to the following hypothesis:

H4: Time has an effective impact in using multimedia technologies in teaching English language.

Performance factor: Performance expectancy is defined as the degree to which an individual believes that using the system will help them to attain gains in job performance [32]. In this research context, performance expectancy refers to the degree to 
which individuals believe that using multimedia technologies will help them to attain gains in personal performance. This study aims to measure the effectiveness of using multimedia on teachers' performance, and this leads to the following hypothesis:

H5: Teachers' performance has an effective impact in using multimedia technologies in teaching English language.

Motivation factor: There is no denying that the success of teaching depends on the interest of students to the subject, and their desire to learn it. However, technological development can critically affect teachers' behavior and expectations. Regarding multimedia in teaching language, the advantages of multimedia combinations of pictures, sound, and text are obvious in teaching; students are in higher motivation to study English by using multimedia [36]. It aids to make the studying process effective, interesting, and accessible [37]. This leads to the following hypothesis:

H6: Motivation has an effective impact in using multimedia technologies in teaching English language.

Pedagogical factor: Pedagogy in education refers to the discipline that deals with the theory and practice of teaching [25]. Pedagogy includes teaching strategies, teacher actions, and teacher judgments, decisions and taking into consideration theories of learning, understandings of students and their needs, and the backgrounds and interests of each student [38]. Pedagogy contains the ways in which teachers communicate with students by asking questions and students respond to it [39]. Therefore, this leads to the following hypothesis:

H7: Pedagogical factor has an effective impact in using multimedia technologies in teaching English language.

Effort factor: Effort expectancy defines as the degree of ease associates with the use of a system [32]. Effort is strong factor towards using technology in teaching and learning. Effort expectancy represents teachers' perception that using the multimedia technologies will be easy and effortless. It is expected that acceptance and continual use of multimedia technologies content will depend on whether teachers perceive the content as easy to use and free of effort [41]. This leads to the following hypothesis:

H8: Effort factor has an effect impact in using multimedia technologies in teaching English language.

Financial factor: The financial factor has an important role in supporting and obtaining multimedia technologies [41]. As it is known, technology aids are quiet expensive. Actually, it is an extra load on teachers. If the ministry of education does not appropriately support teachers with multimedia aids and technologies, the teachers tend not to see the value of these technologies. Also, it leads to lower their interests in using multimedia technologies in their classes. This leads to the following hypothesis:

H9: Financial factor has an effective impact in using multimedia technologies in teaching English language.

Technical factor: Institutions must have adequate land for attractive learning environment to facilitate teaching process such as computers, tablets, data shows, internet networks, and other technical assistances [42]. These technical assistances are very important to add in teaching style, because it makes students creative and innovative. It forms high quality learning. Technical equipment should be provided by the educational institutions as teaching support tools. It needs high cost and periodic mainte- 
nance in order to have a high quality education in institutions [44]. This leads to the following hypothesis:

H10: Technical factor has an effective impact in using multimedia technologies in teaching English language.

Demographic factor: Demographic factor is implementing any system; thus, it is important to test the demographic variable. It includes: Age, gender, computer experience, and teaching experience, as follows:

- Age. Age is very important variable that has influenced directly or indirectly to users' behavior toward technology [32] [44].

- Gender. According to Venkatesh et al. [45], gender differences have been shown to exist in technology-adoption contexts. Furthermore, gender significantly moderates the influence of the determinants on behavior intention.

- Computer experience. Computer experience is considered to be an important key factor in accepting the usage of technology. It widely assumes that participation by users of the information revolution has been fragmented by their attitudes towards computer usage including E-learning [46]. For instance, researchers commonly consider individuals with good technology experiences to have more favorable attitude towards E-learning adoption than individuals with lower levels of technology experiences. Computer experiences facilitate using and adopting multimedia technology in teaching [47].

- Teaching experience. Teaching experience refers to how long teachers spend in working and teaching and how they develop themselves during these working years [48]. Moreover, teaching experience not only relates to years of career but also influences by social life and challenges involved in their jobs. This means that teaching experience is a combination of successful past years with all experience in learning and teaching methods. It is also, a group of motivation, verbal support from principals, supervisors, students, colleagues, and opportunities in learning from their peers and attending their sessions [49].

This research considers the demographic factors and this leads to the following hypothesis:

H11: Demographic factor, such as age, gender, computer experience, and teaching experience have an effective impact in using multimedia technologies in teaching English language.

Behavioral intention factor: Behavioral intention defines as a client's intention to adopt and make use of a certain tool in the future [50]. Moreover, the majority of technology adoption research has utilized behavior intention to predict technology adoption. Therefore, it is essential to examine the intention in using multimedia technologies in teaching. This leads to the following hypothesis:

H12: The behavioral intention factor has an effective impact in using multimedia technologies in teaching English language. 


\subsection{The research questionnaire}

After developing the research model, a questionnaire is designed and the data are collected. The questionnaire was developed to experimentally verify the proposed model, test hypothesis, and gather the necessary information. The study surveys various group of middle schools' English teachers and instructors from different educational areas in Kuwait. Specifically, it focused in the aims to get their point of view about using multimedia technologies in teaching English subject in Kuwait and gathered their experience about using it.

The questionnaire is designed as a multiple choices. It is structured in two main parts; section (A) and section (B). The first part focuses on demographic variables, which are the teacher's age, gender, technology experience, and teaching experience. Section (B) consists of 31 questions that cover the research factors. It uses scale (1-5) that ranged from strongly disagree to strongly agree. The questionnaire is presented in Appendix 1. For example a question from section (B), which covers the facilitation factor in the survey, is as follows:

"At school, I have all the resources (internet, Data show, computers....) necessary to use multimedia technologies in teaching English language skills."

Question number (7), which reflects the knowledge factor, measures the background of teachers' understanding in using multimedia technologies in their classrooms. Teachers will choose from different five levels in each question. The question is as follows:

"I learn all new about multimedia technologies in teaching"

This question expresses teachers' knowledge; it measures teachers' awareness and information they may gain from their experience.

\section{$5 \quad$ Data Analysis and Findings}

This section provides a descriptive statistics of the data collected from the questionnaire that were distributed to the participants of English teachers in middle public schools in Kuwait, both males and females. The quantitative and numerical data is analyzed using Statistical Package for the Social Sciences (SPSS).

The data analysis includes; Crobach's Alpha, T-Test, One Way Anova, Pearson Correlation, and Regression. Crobach's Alpha is used to test reliability and validity of the questionnaire. T- Test and One Way Anova are helping to evaluate the questionnaire respondents and estimate the factors. Moreover, Pearson Correlation and liner regression analyses are used to validate the model and text hypotheses.

In Table 1the study classified demographic distribution of the sample according to the personal variables. This includes five categories (age, gender, area, education, teaching, and technology experiences).

The reliability test is carried out for each of the studied variable. This is done using the Cronbach's Alpha. The scale of Cronbach's Alpha ranges from 0 to 1, but only variables that have reliability values of 0.7 or above is considered reliable. In addition, the Chronbach Alpha for the sample entity answers of the questionnaire questions is 
0.861 , which reflects acceptable reliability for the entities understanding of the questions.

The results in Table 1 show most of respondents are young between (25-34). Females participate more than males with (269) participants. Al-Farwaniya was the highest number of participants. Technology experience shows that most of teachers have excellent use of multimedia technology. The table shows that technology awareness of teachers is very good. It also appears that demographic variables have no impact on using multimedia in teaching, which gives a sign about equality in effort and efficiency between males and females. The validity confirms internal consistence. This reflects reasonable results for the study.

Table 1. The distribution of the sample according to the personal variables

\begin{tabular}{|c|c|c|c|}
\hline Variable & Segments & Count & Percentage \\
\hline \multirow{5}{*}{ Age Categories } & less than 25 years & 34 & $11.2 \%$ \\
\hline & between $25-34$ years & 134 & $44.1 \%$ \\
\hline & between $35-44$ years & 98 & $32.2 \%$ \\
\hline & 45 years or more & 38 & $12.5 \%$ \\
\hline & Total & 304 & $100.0 \%$ \\
\hline \multirow{3}{*}{ Gender } & Male & 35 & $11.5 \%$ \\
\hline & Female & 269 & $88.5 \%$ \\
\hline & Total & 304 & 100.0 \\
\hline \multirow{7}{*}{ Area } & Al-Asma & 49 & $16.1 \%$ \\
\hline & Hawally & 28 & $9.2 \%$ \\
\hline & Farwaniya & 81 & $26.6 \%$ \\
\hline & Al-Ahmedi & 28 & $9.2 \%$ \\
\hline & Al-Jahra & 51 & $16.8 \%$ \\
\hline & Mubarak Al-Kabeer & 67 & $22.0 \%$ \\
\hline & Total & 304 & $100.0 \%$ \\
\hline \multirow{5}{*}{ Multimedia Technologies Experience } & Fair & 4 & $1.3 \%$ \\
\hline & Good & 32 & $10.5 \%$ \\
\hline & Very Good & 133 & $43.8 \%$ \\
\hline & Excellence & 135 & $44.4 \%$ \\
\hline & Total & 304 & $100.0 \%$ \\
\hline
\end{tabular}

Table 2 shows that the Pearson Correlations for the variables are positive and statistically significant. Also, its values are between 0.152 and 0.917 , which reflects an acceptable internal consistency for the answers of the survey questions.

Table 2. Pearson correlation between each item dimension means

\begin{tabular}{|l|c|c|}
\hline \multicolumn{1}{|c|}{ Dimension } & Question & Pearson Correlation \\
\hline \multirow{3}{*}{ 1. Facilitation } & 1 & $.915^{* *}$ \\
\cline { 2 - 3 } 2. Social & 2 & $.636^{* *}$ \\
\cline { 2 - 3 } & 1 & $.560^{* *}$ \\
\cline { 2 - 3 } & 2 & $.680^{* *}$ \\
\cline { 2 - 3 } & 3 & $.603^{* *}$ \\
\cline { 2 - 3 } & 4 & $.717^{* *}$ \\
\hline
\end{tabular}




\begin{tabular}{|c|c|c|}
\hline \multirow{3}{*}{ 3. Knowledge } & 1 & $.546 * *$ \\
\hline & 2 & $.788 * *$ \\
\hline & 3 & $.744 * *$ \\
\hline \multirow{4}{*}{ 4. Time } & 1 & $.152 * *$ \\
\hline & 2 & $.449 * *$ \\
\hline & 2 & $.585 * *$ \\
\hline & 3 & $.642 * *$ \\
\hline \multirow{2}{*}{ 5. Performance } & 1 & $.830 * *$ \\
\hline & 2 & $.874 * *$ \\
\hline \multirow{3}{*}{ 6. Motivation } & 1 & $.900 * *$ \\
\hline & 2 & $.437 * *$ \\
\hline & 3 & $.866^{* *}$ \\
\hline \multirow{2}{*}{ 7. Pedagogical } & 1 & $.842 * *$ \\
\hline & 2 & $.839 * *$ \\
\hline \multirow{2}{*}{ 8. Effort } & 1 & $.774 * *$ \\
\hline & 2 & $.809 * *$ \\
\hline \multirow{4}{*}{ 9. Financial } & 1 & $.478 * *$ \\
\hline & 2 & $.702 * *$ \\
\hline & 3 & $.226^{* *}$ \\
\hline & 4 & $.567 * *$ \\
\hline \multirow{3}{*}{ 10. Technical } & 1 & $.708 * *$ \\
\hline & 2 & $.744 * *$ \\
\hline & 3 & $.428 * *$ \\
\hline \multirow{2}{*}{ 11. Behavioral } & 1 & $.884 * *$ \\
\hline & 2 & $.917 * *$ \\
\hline
\end{tabular}

Table 3 shows that there are positive statistically significant correlations between the behavioral factor and each of Facilitation, Social, Performance, Motivation, Pedagogical, and Financial factors, with (P-values $<0.05)$. For example the P-value for facilitation factor is $(0.000)$, which is smaller than 0.05 , and the Pearson correlation is (0.347), which shows strong correlation. However, there is no Pearson correlation between behavioral factor, knowledge, time, effort and technical factors (P-value > $0.05)$.

Table 3. Pearson correlation between behavioral factor and the other factors.

\begin{tabular}{|l|c|c|c|}
\hline \multicolumn{1}{|c|}{ Factor } & Sample size & Pearson Correlation & P-value \\
\hline 1. Facilitation & 304 & $* * .347$ & .000 \\
\hline 2. Social & 304 & $* * .413$ & .000 \\
\hline 3. Knowledge & 304 & .110 & .054 \\
\hline 4. Time & 304 & $*-.133$ & .021 \\
\hline 5. Performance & 304 & $* * .526$ & .000 \\
\hline 6. Motivation & 304 & $* * .582$ & .000 \\
\hline 7. Pedagogical & 304 & $* * .513$ & .000 \\
\hline 8. Effort & 304 & $*-.128$ & .025 \\
\hline 9. Financial & 304 & $* * .151$ & .008 \\
\hline 10. Technical & 304 & .002 & .973 \\
\hline
\end{tabular}


Table 4 summarizes the results for all the hypotheses in this research. There are 12 hypotheses in this research and based on the t-test and ANOVA for the demographics and the regression results for the studied variables, the hypotheses have been answered.

Table 4. Hypotheses result summary

\begin{tabular}{|c|c|c|}
\hline Hypothesis & $\begin{array}{c}\text { Result (Supported / } \\
\text { Reject) }\end{array}$ & Relationship Strength \\
\hline $\begin{array}{l}\text { H1: Facilitation factor has an effective impact on mul- } \\
\text { timedia technologies in teaching English language. }\end{array}$ & Supported & $\begin{array}{l}\text { Average } \\
\mathrm{B}=.110\end{array}$ \\
\hline $\begin{array}{l}\text { H2: Social factor has an effect impact on using multi- } \\
\text { media technologies in teaching English language. }\end{array}$ & Supported & $\begin{array}{l}\text { Average } \\
\mathrm{B}=.217\end{array}$ \\
\hline $\begin{array}{l}\text { H3: The knowledge has an effective impact in using } \\
\text { multimedia technologies in teaching English language. }\end{array}$ & Rejected & No influence \\
\hline $\begin{array}{l}\text { H4: Time has an effective impact in using multimedia } \\
\text { technologies in teaching English language }\end{array}$ & Rejected & No influence \\
\hline $\begin{array}{l}\text { H5: Teachers' performance has an effective impact in } \\
\text { using multimedia technologies in teaching English } \\
\text { language. }\end{array}$ & Supported & $\begin{array}{l}\text { Strong } \\
\mathrm{B}=.246\end{array}$ \\
\hline $\begin{array}{l}\text { H6: Motivation has an effective impact in using multi- } \\
\text { media technologies in teaching English language. }\end{array}$ & Supported & $\begin{array}{l}\text { Strong } \\
\mathrm{B}=.304\end{array}$ \\
\hline $\begin{array}{l}\text { H7: The pedagogical factor has an effective impact in } \\
\text { using multimedia technologies in teaching English } \\
\text { language. }\end{array}$ & Supported & $\begin{array}{l}\text { Strong } \\
\mathrm{B}=.128\end{array}$ \\
\hline $\begin{array}{l}\text { H8: Effort factor has an effect impact in using multime- } \\
\text { dia technologies in teaching English language. }\end{array}$ & Supported & $\begin{array}{l}\text { Weak } \\
\mathrm{B}=-.097\end{array}$ \\
\hline $\begin{array}{l}\text { H9: The financial factor has an effective impact in using } \\
\text { multimedia technologies in teaching English language. }\end{array}$ & Rejected & No influence \\
\hline $\begin{array}{l}\text { H10: The technical factor has an effective impact in } \\
\text { using multimedia technologies in teaching English } \\
\text { language. }\end{array}$ & Rejected & No influence \\
\hline H11: Demographic factor: Age, gender, and experience. & Rejected & No influence \\
\hline $\begin{array}{l}\text { H12: The behavioral factor has an effective impact in } \\
\text { using multimedia technologies in teaching English } \\
\text { language. }\end{array}$ & Supported & Linear regression \\
\hline
\end{tabular}

\section{Discussion}

This section presents the findings and answers the research questions in the light of conducted data analysis, as follows:

What are the effective factors influencing the usage of multimedia technologies in teaching English language in middle public schools in Kuwait?

Based on the correlation and regression tests that are carried out, there are some factors having relation and others that have no impact. According to ANOVA and Coefficient Regression tests, there are five factors having no relation in the study, which are; knowledge, financial, technical, time, and demographic factors, which 
include; age, gender, and experience variables. On the contrary, seven factors have relation in the study. These factors are facilitation, social, motivation, performance, effort, and behavioral factors. All the related factors are positive except effort, which reflects negative weak relation.

These factors replicate the importance of using multimedia technologies in teaching. These are the factors that are significant to teachers in Kuwait if they intent to use multimedia technologies in their classrooms. Therefore, there is strong positive statistically significant correlation between the behavioral factor and the utilization of multimedia with these factors.

Regression between the behavioral factor and the other factors is valid, F-test= 26.4 and the $\mathrm{P}$-value $=0, \mathrm{P}$-value $<0.05$. The result reflects the positive influence the behavioral factor has in using multimedia in teaching and learning.

Does the multimedia increases teachers' motivation?

The description of means and statistical analysis for the questionnaire shows agreement in responses, which reflects strong and positive attitude towards using multimedia technologies in increasing teachers' motivation $(\mathrm{B}=0.304)$. On the other hand, the correlation test which should be with P-values $<.05$, shows strong relation with (.582) value, because teachers find big motivation in using multimedia technologies. Although the responsible in the ministry of education do not provide any technical support, that due to lack of technical and financial supplements at public schools in Kuwait. It also displays no satisfaction from teachers of technical and maintenance support.

Public schools in Kuwait should be an attractive environment for both teachers and students. Educational institutions should be more serious in developing education in Kuwait. Moreover, government departments should pay attention to improve teacher motivation by encouraging teacher to use multimedia technologies by managing workshops and training courses. They also must provide materials and technical support to raise the level of education in our schools.

\section{Do the multimedia technologies facilitate teachers' work?}

It is important to measure the abilities of multimedia technologies in enhancing and simplifying the teachers' work. The statistical analysis for the survey about this question indicates positive effect and strong relation with $(\mathrm{B}=0.110)$. The relation shows positive average regression. There is an average positive relation between behavioral intention and facilitation factor, which reflects the confident power of multimedia technologies in teaching.

Also, the correlation results show affirmative relation between behavioral and facilitation factors with $\mathrm{P}$-value $=0.000<0.05$ value. This reflects strong impact of multimedia on teaching process. The answer of this question confirms the significance of using multimedia technologies in teaching English language. Therefore, teachers must use multimedia technologies in their work as facilitation aid side by side with their curriculum book and traditional teaching materials.

Does the technical issue affect teachers to use multimedia technologies?

The means and the statistical analysis of survey confirm nearly neutral responses and this is the result of the lack of effective support from the Ministry of Education. The ministry should give schools continuous maintenance and technical support for 
all technology aids. Also, they must provide all the requirements of modern technology at schools. Teachers must not buy any educational aid from their own money.

As the correlation results, there is no relation between the utilization of multimedia technologies and technical factor. The correlation value is $(0.002)$. The p-value is (0.973), which reflects no relation. It should be less than 5. Concerning the development of technology is very important in the classrooms. Technical problems still needs productive solutions. Also the educational institutions must overcoming the finance and the technical problems in setting up the infrastructure and not allowing the teachers to fear from using it, which leads at the end to lack of motivation.

Does the social factor affect teachers' behavioral intention to use multimedia technologies in teaching?

The means and the statistical analysis of survey shown above agreement level, which reflects the positive value of this factor. Also it shows the cooperative society in educational environment. Teachers inside their field of work can learn from each other and exchange information as well as experiences. In addition, the relationship between the social factor and the behavioral to use multimedia technologies is studied by both correlation and regression. The results show supported value with P-value $(0.000)$ and the correlation is $(0.413)$, which reveals the pessimistic outlook the society carries about multimedia technologies. It also shows the lack of awareness of the surrounded society in educational institutions. This is leads to the fact that Kuwait still new born in using technology in education. These proofs support the previous studies about Kuwait technology awareness and usage in education.

What is the effect of multimedia technologies in the level of students' understanding?

The one of the most important aim of multimedia language in teaching is to encourage students and inspire their motivation to learn. Without multimedia technology, English language learners are often left to their own devices. The answer of this question is positive because the results show strong correlation of performance (0.526) with $\mathrm{p}$-value $=0.000<0.05$; pedagogy correlation $(0.513)$, $\mathrm{p}$-value $=0.000$ $<0.05$; and facilitation factors correlation $(0.347)$ with $p$-value $=0.000<0.05$. Therefore, performance of teachers inside the class increases students' understanding. Also, the clarification of curriculum, teaching methods, ways, and styles will be more obvious to students to gain.

\section{Conclusion}

This study aims to find out the influencing factors of using multimedia technologies through measuring the satisfaction and convenience of the instructors in Kuwait. The research used survey questionnaire method that was distributed for both male and female instructors in middle public schools. The findings show that some factors have influence, which are: facilitation, motivation, performance, behavioral, social, and pedagogical and effort factors. However other factors that do not have influence are: knowledge, financial, technical, time, and demographic factors. 
Regarding the improvement of technology, we trust that in future, the use of internet and multimedia technologies in English teaching will be more developed in $\mathrm{Ku}$ wait. The process of English learning will be more student-centered. Therefore, the ministry of education must promise that the teaching quality will be improved within multimedia technologies. The recommendation for future research is to study the affection of using multimedia intended for high schools and be more specific in males' schools or females' schools and make comparison between them. In addition, more research papers and studies should be conducted in using multimedia technologies in teaching English language in Kuwait in private schools, high schools and universities. It can also conduct studies focus on challenges and negative factors that may effect on using multimedia technologies in teaching English language in Kuwait.

\section{References}

[1] Zhou.Xuan,(2015).The development of multimedia in foreign linguistics teaching for higher education, college of foreign language education,Beihua university,Jilin,China.

[2] Sangrà, Vlachopoulos,Cabrera,(2012). Building an Inclusive Definition of E-Learning: An Approach to the Conceptual Framework. Universitat Oberta de Catalunya, Spain.

[3] Webcrawler, C. (2013). Definition of Educational Media. California: Retrieved from http://www.ask.com/question/meaning-ofeducational-media on August, 12013.

[4] Rania Mohammed Fatehi, "The Effectiveness of Using Subtitled Video to Teach Grammar" (2013). GraduateTheses and Dissertations. http://lib.dr.iastate.edu/etd/13057.

[5] Enriquez.S.Mark Angelo,(2014).students' perceptions on the effectiveness of the use of Edmodo as a supplementary tool for learning, the university lady Fatima,Valenzuela city campus, Philippines.

[6] Al-Mutairi (2017), the impact of application of Information and Communication Technologies (ICT) in learning and teaching English language in girls' primary schools in Kuwait. Thesis, Kuwait University.

[7] Al-Hunaiyyan, A., Alhajri, R. A., \& Al-Sharhan, S. (2016). Perceptions and challenges of mobile learning in Kuwait. Journal of King Saud University-Computer and Information Sciences. https://doi.org/10.1016/i.jksuci.2016.12.001

[8] Solomon, D. L. (2000). Toward a post-modern agenda in Instructional Technology. Educational Technology Research and Development, 48 (4), 5-20. https://doi.org/10.1007/bf023 $\underline{00497}$

[9] Marc J. Rosenberg, (2002). E-Learning: strategies for delivering knowledge in the digital age, New York, NY: McGraw-Hill Companies, Inc., 343 pages, ISBN: 0-07-136268-1.

[10] Clark Ruth, Mayer,(2016).The book of E-learning and the science of instruction.USA.

[11] Nuraini, Mohd, Shahbodin (2016), using personalized environment approach for nutrition topic, Department of Media Interactive, Faculty of Information Technology and Communication University Teknikal Malaysia Melaka, Hang Tuah Jaya, Durian Tunggal, Melaka, Malaysia. https://doi.org/10.30880/ijie.2019.11.03.026

[12] Chen and Sun, (2011). The study of integration of multimedia network and English Teaching, college of economic and management college of foreign languages, Tianjin, China.

[13] Rynson Lau \& Neil Yen \& Frederick Li \& Benjamin Wah, (2013).Recent development in multimedia e-learning technologies,department of computer science and engineering ,university of Hong Kong,university of Aizu,university of Duham,UK. 
[14] Smedley, J.K. (2010). Modelling the impact of knowledge management using technology. OR Insight (2010) 23, 233-250. https://doi.org/10.1057/ori.2010.11

[15] Wagner, N., Hassanein, K. \& Head, M. (2008). Who is responsible for E-learning in Higher Education? A Stakeholders' Analysis. Educational Technology \& Society, 11 (3), 2636.

[16] Henich, R. (2002). Instructional media and technologies for learning. Beijing: Higher Education Press.

[17] Arkorful.V, Abaidoo.N,(2014). The role of e-learning, the advantages and disadvantages of its adoption in Higher Education. College of Distance Education, University of Cape Coast. Ghana.

[18] Mayes, T., \& De Freitas, S. (2004). Review of e-learning theories, frameworks and models. JISC e-learning models desk study, (1).

[19] Mayer, R. E. (2002). Cognitive theory and the design of multimedia instruction: an example of the two-way street between cognition and instruction. New directions for teaching and learning, 2002(89), 55-71. https://doi.org/10.1002/tl.47

[20] Ramírez, M. (2012). Usage of Multimedia Visual Aids in the English Language Classroom: A Case Study at Margarita Salas Secondary School (Majadahonda). Unpublished Masters Dissertation). Matritensis University, Spain.

[21] Yunus, M. M., Salehi, H., \& John, D. S. A. (2013). Using visual aids as a motivational tool in enhancing students interest in reading literary texts. arXiv preprint arXiv:1305.6360.

[22] Mohammed, Rania Fatehi, "The Effectiveness of Using Subtitled Video to Teach Grammar" (2013). GraduateTheses and Dissertations, http://lib.dr.iastate.edu/etd/13057.

[23] Inan, Fethi \& Lowther, Deborah. (2010). Factors affecting technology integration in K-12 classrooms: A path model. Educational Technology Research and Development. 58. 137154. https://doi.org/10.1007/s11423-009-9132-y.

[24] Saadé, Galloway, (2005). "Toward an Understanding of the Behavioral Intention to Use an Information System".John Molson School of Business, Concordia University Montreal, Quebec, Canada.

[25] Tarhini, Hone, Liu (2013)," Factors Affecting Students' Acceptance of E-Learning Environments in Developing Countries: A Structural Equation Modeling Approach". International Journal of Information and Education Technology, Vol. 3, No. 1, February 2013,Lebanon. https://doi.org/10.7763/ijiet.2013.v3.233

[26] Albirini, Abdulkafi. (2006). Teachers' attitudes toward information and communication technologies: The case of Syrian EFL teachers. Computers \& Education. 47. 373-398. https://doi.org/10.1016/i.compedu.2004.10.013.

[27] Gilakjani, A., \& Ahmadi, A. (2011). A study of factors affecting EFL learners' English listening comprehension and the strategies for improvement. Journal of Language Teaching and Research, 2(5), 977-988. https://doi.org/10.4304/jltr.2.5.977-988

[28] Al-Doub, E., Goodwin, R., \& Al-Hunaiyyan, A. (2008). Student's attitudes toward elearning in Kuwait's higher education institutions. Retrieved October, 15, 2010.

[29] Aloraini, S. (2012). The impact of using multimedia on students' academic achievement in the College of Education at King Saud University. Journal of King Saud UniversityLanguages and Translation, 24(2), 75-82. https://doi.org/10.1016/j.jksult.2012.05.002

[30] Gokah, T.K. \& Gupta, N. \& Ndiweni, Esinath. (2015). E-learning in higher education Opportunities \& challenges for Dubai. International Journal on E-Learning: Corporate, Government, Healthcare, and Higher Education. 14. 443-470.

[31] Alkharang, M. M., \& Ghinea, G. (2013). E-learning in higher educational institutions in Kuwait: Experiences and challenges. E-learning, 4(4), 1-6. 
[32] Venkatesh, Viswanath; Morris, Michael G.; Davis, Gordon B.; Davis, Fred D. (2003). "User Acceptance of Information Technology: Toward a Unified View". MIS Quarterly. 27 (3): 425-478. https://doi.org/10.2307/30036540

[33] Alkharang, M. M. (2014). Factors that influence the adoption of e-learning: an empirical study in Kuwait (Doctoral dissertation, Brunel University London).

[34] Venkatesh, V., Thong, J. Y. L., \& Xu, X. (2012). Consumer acceptance and use of information technology: Extending the unified theory of acceptance and use of technology. MIS Quarterly, 36(1), 157-178. https://doi.org/10.2307/41410412

[35] Baylor, A. L., \& Ritchie, D. (2002). What factors facilitate teacher skill, teacher morale, and perceived student learning in technology-using classrooms? Computers \& education, 39(4), 395-414. https://doi.org/10.1016/s0360-1315(02)00075-1

[36] Joshi, Ashvini. "Multimedia: A Technique in Teaching Process In the Classroom." Current World Environment (2012): 33-36.

[37] Sharma, H. L., \& Pooja, L. (2016). Enhancing students' interest in English language viamultimedia presentation. International Journal of Applied Research, 2(1), 275-281.

[38] Shulman, L. S. (1987). Shulman, Lee S.," Knowledge and Teaching: Foundations of the New Reform," Harvard Educational Review, 57 (February, 1987), 1-22. https://doi.org/1 0.17763/haer.57.1.j463w79r56455411

[39] Hodgins, W. (2002). The future of learning objects. In The Instructional Use of Learning Objects, edited by D. A. Wiley, 281-298. Bloomington, Indianan, USA.

[40] Dillon, A. and Morris, M. (1996) User acceptance of new information technology: theories and models. In M. Williams (ed.) Annual Review of Information Science and Technology, Vol. 31, Medford NJ: Information Today, 3-32.

[41] Kisanga and Ireson.(2015). Barriers and strategies on adoption of e-learning in Tanzanian higher learning institutions: Lessons for adopters, International Journal of Education and Development using Information and Communication Technology (IJEDICT), 2015, Vol. 11, Issue 2, pp. 126-137, Nottingham Trent University, UK.

[42] Bolliger, D. U., \& Wasilik, O. (2009). Factors influencing faculty satisfaction with online teaching and learning in higher education. Distance Education, 30(1), 103-116. https://doi. org $/ 10.1080 / 01587910902845949$

[43] Puyate, S. T., \& Okwakpam, I. N. (2011). Technical teachers' factors that influence students'academic performance in industrial education. Problems of Education in the 21st Century, 31.

[44] Schodt, Paul. (2002). "The relationship between organizational identification and Organizational culture: Employee perceptions of culture in a retail sales organization", Communication studies, vol.53 no. 2, p. 189. https://doi.org/10.1080/10510970209388584

[45] Venkatesh, V., Morris, M. G., \& Ackerman, P. L. (2000). A longitudinal field investigation of gender differences in individual technology adoption decision-making processes. Organizational behavior and human decision processes, 83(1), 33-60. https://doi.org/10.10 06/obhd.2000.2896

[46] Karjaluoto, H., Mattila, M., \& Pento, T. (2002). Factors underlying attitude formation towards online banking in Finland. International journal of bank marketing, 20(6), 261-272. https://doi.org/10.1108/02652320210446724

[47] Trocchia, P. J., \& Janda, S. (2000). A phenomenological investigation of Internet usage among older individuals. Journal of consumer marketing, 17(7), 605-616. https://doi.org/1 $\underline{0.1108 / 07363760010357804}$

[48] Klassen, R. M., \& Chiu, M. M. (2010). Effects on teachers' self-efficacy and job satisfaction: Teacher gender, years of experience, and job stress. Journal of educational Psychology, 102(3), 741. https://doi.org/10.1037/a0019237 
[49] Tschannen-Moran, M., Hoy, A. W., \& Hoy, W. K. (1998). Teacher efficacy: Its meaning and measure. Review of educational research, 68(2), 202-248. https://doi.org/10.3102/00 $\underline{346543068002202}$

[50] AJZEN, I. (1991). The theory of planned behavior. Organizational behavior and human decision processes, 50, 179-211. https://doi.org/10.1016/0749-5978(91)90020-t

[51] Abdulaziz Omar Alsadhan, Sami Alhomod, Mohd Mudasir Shafi, Multimedia Based Elearning: Design and Integration of Multimedia Content in E-learning, International Journal of Emerging Technologies in Learning, Vol 9, No 3. https://doi.org/10.3991/ijet.v9i3. $\underline{3308}$

[52] Yue Zheng (2019), Inquiry Based Teaching in an Animation Multimedia Course, Int Journal of Emerging Technologies in Learning, Vol 14, No 17

[53] Mengqing Han, Shanshan Niu (2019), Effect of Computer Multimedia Assisted Word Annotation on Incidental Vocabulary Acquisition of English Reading, International Journal of Emerging Technologies in Learning, Vol 14, No 13. https://doi.org/10.3991/ijet.v14i13.10 $\underline{705}$

\section{Authors}

Najla'a Aj-Ajmi is an English teacher in public schools in Kuwait. She has an experience in teaching for eleven years in middle schools for girls. She received her Bachelor degree in teaching English from College of Education in Kuwait University in 2008 and her Master degree in Information Technology from Kuwait University in 2018. She received a certificate in behavioral trainer from Kuwait University and the Ministry of Education in 2014.Al-Ajmi interests in Education, Teaching English, and E-Learning.

Zainab Aljazzaf is an assistant professor at Kuwait University, College of Life Sciences, Department of Information Science, Kuwait University. She received her Bachelor degree in Computer Engineering from Kuwait University in 1997 and her Master degree in Computer Engineering from Kuwait University in 2005. Aljazzaf got her PhD in Computer Science from Western Ontario University, Ontario, Canada in December, 2011. Aljazzaf joined Kuwait University as a faculty member in January, 2012. Aljazzaf research interests include Web services, Service Oriented Computing, Cloud Computing, Trust, E-government, and E-learning. She has published a number of Journal and conference papers.

Article submitted 2019-11-09. Resubmitted 2019-12-05. Final acceptance 2019-12-08. Final version published as submitted by the authors. 


\section{Appendix:}

\subsection{Survey questionnaire}

\begin{tabular}{|c|c|}
\hline Factors & Questions \\
\hline 1 & Demographic, it includes: Age, Gender, Technology experience, and teaching experience. \\
\hline \multirow[t]{2}{*}{2} & $\begin{array}{l}\text { 1-At school, I have all the resources (internet, Data show, computers....) necessary to use multi- } \\
\text { media technologies in teaching English language skills. }\end{array}$ \\
\hline & 2-Multimedia technologies assist to present my English language lesson. \\
\hline \multirow{4}{*}{3} & 3-It is important to use multimedia technologies in teaching English skills. \\
\hline & $\begin{array}{l}\text { 4-My colleagues are encouraging me and motivating me to use multimedia technologies in teach- } \\
\text { ing. }\end{array}$ \\
\hline & 5-The supervision insists to make us use multimedia technologies in teaching. \\
\hline & 6-The ministry of education supports using multimedia technologies in teaching. \\
\hline \multirow{3}{*}{4} & 7-I learn all new about multimedia technologies in teaching. \\
\hline & $\begin{array}{l}\text { 8-The ministry of education provides training courses for all the middle schools teachers to use } \\
\text { multimedia technologies in classrooms. }\end{array}$ \\
\hline & 9-My school prepares classrooms with all new multimedia technologies needed in teaching. \\
\hline \multirow{4}{*}{5} & 10- I have enough time to prepare my lessons using multimedia technologies. \\
\hline & 11-I spend a lot of time on my computer at home preparing my lessons. \\
\hline & 12-Using multimedia technologies in every class is wasting my time. \\
\hline & 13-I don't have time to attend training courses about multimedia technologies. \\
\hline \multirow{2}{*}{6} & 14-I know how to employ multimedia technologies in teaching my lessons. \\
\hline & 15-I find multimedia technologies enhanced my teaching performance. \\
\hline 7 & $\begin{array}{l}\text { 16-Using multimedia technologies in teaching English language increases my students' motivation, } \\
\text { interests and achievement }\end{array}$ \\
\hline 8 & 17Multimedia technologies make an enjoyable atmosphere for students in my classrooms. \\
\hline \multirow{3}{*}{9} & 18-Using multimedia technologies in teaching makes learning exciting and attractive. \\
\hline & $\begin{array}{l}\text { 19-I believe that multimedia technologies enable the students to apply knowledge in different } \\
\text { situations. }\end{array}$ \\
\hline & 20-Multimedia technologies improve my students' understanding. \\
\hline \multirow{2}{*}{10} & 21-I believe that using multimedia technologies in every lesson is tiring. \\
\hline & 22-I make great efforts in explaining my lesson by using multimedia technologies. \\
\hline \multirow{4}{*}{11} & 23-Multimedia technologies are worth the investment. \\
\hline & 24-I spend a lot of money to buy multimedia technologies. \\
\hline & 25-The ministry of education provides all multimedia technologies at school for free charge. \\
\hline & 26-The cost of buying multimedia technologies used in teaching is very high. \\
\hline \multirow{3}{*}{12} & 27-The speed of the internet is slow down sometimes. \\
\hline & 28-I face many technical problems while using multimedia technologies in teaching. \\
\hline & 29-Pictures and videos are simple and fast to be downloaded. \\
\hline \multirow{2}{*}{13} & 30-I intend to continue explaining my lessons using multimedia technologies in the future. \\
\hline & 31-I will always use multimedia technologies in my classrooms. \\
\hline
\end{tabular}

